\title{
Effects of exogenous big endothelin-1 on postischemic cardiac dysfunction and norepinephrine overflow in rat hearts
}

\begin{abstract}
Masashi Tawa ${ }^{1,2}$, Taiki Fukumoto ${ }^{1}$, Mamoru Ohkita ${ }^{1}$, Naoto Yamashita ${ }^{1}$, Ayman Geddawy ${ }^{2}$, Takeshi Imamura ${ }^{2}$, Kazuhide Ayajiki ${ }^{2}$, Tomio Okamura ${ }^{2}$ and Yasuo Matsumura ${ }^{1}$

Endothelin-1 (ET-1) is involved in norepinephrine (NE) overflow and cardiac dysfunction after myocardial ischemia/reperfusion via the activation of $\mathrm{ET}_{\mathrm{A}}$ receptors. As ET-1 is generated from big ET-1 via endothelin-converting enzyme (ECE), ischemia/ reperfusion-induced cardiac injury may be exacerbated by exogenous big ET-1. The aim of this study was to investigate the influence of exogenously applied big ET-1 on ischemia/reperfusion-induced NE overflow and cardiac dysfunction. According to the Langendorff technique, isolated rat hearts were subjected to 40-min global ischemia followed by 30-min reperfusion. Exogenous big ET-1 (0.1, 0.3 and $1 \mathrm{~nm})$ was perfused, beginning $15 \mathrm{~min}$ before ischemia. Unexpectedly, higher doses $(0.3$ and $1 \mathrm{nm)} \mathrm{of} \mathrm{big} \mathrm{ET-1} \mathrm{significantly} \mathrm{improved} \mathrm{indices} \mathrm{of} \mathrm{left} \mathrm{ventricular} \mathrm{function} \mathrm{after} \mathrm{ischemia/reperfusion,} \mathrm{such} \mathrm{as} \mathrm{left} \mathrm{ventricular}$ developed pressure (LVDP), the maximum value of the first derivative of left ventricular pressure ( $\mathrm{dP} / \mathrm{dt}_{\max }$ ) and left ventricular end diastolic pressure (LVEDP). In addition, big ET-1 significantly suppressed excessive NE overflow in the coronary effluent from the postischemic heart. These effects of big ET-1 were markedly attenuated by treatment with SM-19712 (selective ECE inhibitor) or A-192621 (selective $\mathrm{ET}_{\mathrm{B}}$ receptor antagonist). On the other hand, those were not potentiated even though combined with ABT-627 (selective $\mathrm{ET}_{A}$ receptor antagonist). From these findings, we suggest that exogenous big ET-1 has beneficial effects on ischemia/reperfusion-induced cardiac injury. It seems likely that big ET-1 is converted to ET-1, locally in the heart, and this ET-1 preferentially binds to $\mathrm{ET}_{\mathrm{B}}$ receptors to exert its related beneficial actions.
\end{abstract}

Hypertension Research (2011) 34, 218-224; doi:10.1038/hr.2010.213; published online 4 November 2010

Keywords: big endothelin-1; endothelin-1; ischemia/reperfusion; norepinephrine

\section{INTRODUCTION}

Endothelin-1 (ET-1) was originally found as a 21-amino-acid vasoconstrictor peptide produced by vascular endothelial cells. ${ }^{1}$ This peptide is most abundant in the cardiovascular system, and at least two distinct $\mathrm{ET}$ receptors, $\mathrm{ET}_{\mathrm{A}}$ and $\mathrm{ET}_{\mathrm{B}}$, have been identified. $\mathrm{ET}_{\mathrm{A}}$ receptors mediate vasoconstriction and cell proliferation, whereas $\mathrm{ET}_{\mathrm{B}}$ receptors are important for the clearance of ET-1, endothelial cell survival, the release of nitric oxide and prostacyclin. ${ }^{2}$

There is accumulating evidence that ET- 1 is closely related to the pathogenesis and development of several cardiovascular diseases. ${ }^{3,4}$ It has been demonstrated that ischemia increases ET-1-binding sites in cardiac membranes. ${ }^{5}$ In addition, we have recently noted that left ventricular ET-1 content is increased by ischemia/reperfusion in isolated rat hearts, and postischemic cardiac dysfunction is improved by suppressing the ET-1 biosynthesis. ${ }^{6}$ These findings imply that endogenously generated ET-1 plays an important role in the pathophysiology of myocardial ischemia/reperfusion. Indeed, both selective
$\mathrm{ET}_{\mathrm{A}}$ receptor antagonists and non-selective $\mathrm{ET}_{\mathrm{A}} / \mathrm{ET}_{\mathrm{B}}$ receptor antagonists exhibited protective effects against the postischemic cardiac dysfunction. $^{7-10}$

Enhancement of cardiac sympathetic nerve activity and its consequent effect on norepinephrine (NE) overflow from the nerve endings has also been considered as a factor that aggravates cell damage in ischemic myocardium. ${ }^{1}$ In fact, it has been demonstrated that the negative modulation of NE release significantly suppresses postischemic cardiac dysfunction. ${ }^{11-13}$ We have found that endogenously generated ET-1 evokes NE overflow via the stimulation of $\mathrm{ET}_{\mathrm{A}}$ receptors, and this contributes to cardiac deterioration after ischemia/reperfusion. ${ }^{6,10}$ Moreover, Isaka et al. have demonstrated that both $\mathrm{ET}_{\mathrm{A}}$ and $\mathrm{ET}_{\mathrm{B}}$ receptors exist in the sympathetic nerve varicosities of guinea pig hearts, and modulate NE release in association with reperfusion arrhythmias. ${ }^{14}$ Taken together, it is considered that endogenously generated ET-1 promotes postischemic NE overflow, and this is contributive, at least in part, to subsequent cardiac dysfunction.

${ }^{1}$ Laboratory of Pathological and Molecular Pharmacology, Osaka University of Pharmaceutical Sciences, Takatsuki, Osaka, Japan and ${ }^{2}$ Department of Pharmacology, Shiga University of Medical Science, Otsu, Shiga, Japan

Correspondence: Dr Y Matsumura, Laboratory of Pathological and Molecular Pharmacology, Osaka University of Pharmaceutical Sciences, 4-20-1 Nasahara, Takatsuki, Osaka 569-1094, Japan.

E-mail: ymatsumura@gly.oups.ac.jp

Received 7 July 2010; revised 5 August 2010; accepted 8 August 2010; published online 4 November 2010 
ET-1 is generated from an intermediate form termed big ET-1 via a specific cleavage at $\operatorname{Trp}^{21}$ and $\mathrm{Val}^{22}$ by the protease endothelinconverting enzyme (ECE), which is expressed in various cardiovascular tissues, including the endocardium and myocardium. ${ }^{15}$ Big ET-1 is known to exert a vasoconstrictive effect, probably by converting into ET-1. ${ }^{16-18}$ Using isolated rat hearts, Grover et al. have shown that exogenous big ET-1 reduces coronary flow (CF) similar to exogenous ET- $1 .{ }^{19}$ Therefore, there is a possibility that exogenously applied big ET-1 exerts a similar effect to ET-1 in the heart exposed to ischemia/ reperfusion. In this study, we investigated the effect of exogenously applied big ET-1 on ischemia/reperfusion-induced NE overflow and cardiac dysfunction.

\section{METHODS}

\section{Animals}

Male Sprague-Dawley rats (weight 250-350 g, Japan SLC, Shizuoka, Japan) were used. The animals were housed in a light-controlled room with a $12-\mathrm{h}$ light/dark cycle and were allowed ad libitum access to food and water. Experimental protocols and animal care methods were approved by the Experimental Animal Research Committee of Osaka University of Pharmaceutical Sciences.

\section{Isolated rat heart preparation}

Animals were anesthetized with sodium pentobarbital (50 $\mathrm{mg} \mathrm{kg}^{-1}$, i.p.). Hearts were rapidly excised, connected via the aorta to Langendorff apparatus (IPHW2, Labo Support, Osaka, Japan) and perfused in a retrograde manner at a constant pressure of $80 \mathrm{~mm} \mathrm{Hg}$ with perfusate (Krebs-Henseleit solution) of the following composition (mM): $\mathrm{NaCl} 118.1, \mathrm{KCl} 4.6, \mathrm{CaCl}_{2} 2.5, \mathrm{MgSO}_{4}$ 1.2, $\mathrm{KH}_{2} \mathrm{PO}_{4} 1.2, \mathrm{NaHCO}_{3} 24.8$, glucose 10. The perfusate was bubbled continuously with a gas mixture of $95 \% \mathrm{O}_{2} / 5 \% \mathrm{CO}_{2}$ (pH 7.4), and the temperature was maintained at $37^{\circ} \mathrm{C}$ throughout the experiment. A latex balloon filled with water was inserted into the left ventricle through the left atrium and attached to a pressure transducer (DX-360, Nihon Kohden, Osaka, Japan). Left ventricular developed pressure (LVDP) and left ventricular end diastolic pressure (LVEDP) were measured by an amplifier for pressure measurement (AP601G, Nihon Kohden); the maximum value of the first derivative of left ventricular pressure $\left(\mathrm{dP} / \mathrm{dt}_{\max }\right)$ was measured with a derivative operation unit (EQ $621 \mathrm{G}$, Nihon Kohden), and these parameters were recorded with PowerLab/4sp (ADInstruments, Castle Hill, Australia). CF was also monitored. The balloon volume was adjusted to provide an LVEDP of $10 \mathrm{~mm} \mathrm{Hg}$. After stabilization for 20-30 min, the experiment was started.

\section{Experimental protocol}

Hearts were subjected to global ischemia for $40 \mathrm{~min}$ by clamping of the aortic cannula, followed by reperfusion for $30 \mathrm{~min}$. Exogenous big ET-1 (0.1-1 nM) was perfused from $15 \mathrm{~min}$ before ischemia and until $5 \mathrm{~min}$ after onset of reperfusion. In case of pretreatment with a selective ECE inhibitor SM-19712 $(10 \mu \mathrm{M}),{ }^{20}$ a selective $\mathrm{ET}_{\mathrm{B}}$ receptor antagonist A-192621 $(3 \mu \mathrm{M})^{21}$ or a selective $\mathrm{ET}_{\mathrm{A}}$ receptor antagonist ABT-627 $(3 \mu \mathrm{M}),{ }^{22}$ perfusion of each antagonist was started $15 \mathrm{~min}$ before perfusion of $0.3 \mathrm{~nm}$ big ET- 1 and was continued until finishing the experiment. Aliquots of coronary effluent were collected for assay for $5 \mathrm{~min}$ after onset of reperfusion.

\section{ET-1 radioimmunoassay}

Aliquots of coronary effluent $(1 \mathrm{ml})$ in each experiment were diluted 1/10 with a $0.09 \%$ trifluoroacetic acid solution and applied to Sep-Pak C18 cartridges (Nihon Waters KK, Tokyo, Japan). The sample was eluted with $4 \mathrm{ml}$ of $63.3 \%$ acetonitrile and $0.1 \%$ trifluoroacetic acid in water. Elutes were dried in a centrifugal concentrator and the dried residue was reconstituted in assay buffer for radioimmunoassay. The clear solution was subjected to radioimmunoassay. The recovery of ET- 1 was $\sim 80 \%$. Radioimmunoassay for ET-1 was performed, as described previously. ${ }^{6}$

\section{NE assay}

$\mathrm{NE}$ in the coronary effluent was measured with high-performance liquid chromatography and an amperometric detector (ECD-100, Eicom, Kyoto, Japan), as reported previously. ${ }^{6}$

\section{Isolation of total RNA, synthesis of cDNA and quantitative real-} time reverse transcriptase-PCR analysis

Total RNA was extracted from isolated rat left ventricle by TRI REAGENT (Molecular Research Center, Cincinnati, OH, USA) according to the instructions from the manufacturer. RNA was purified by TURBO DNA-free kit (Applied Biosystems/Ambion, Austin, TX, USA). Real-time reverse transcriptase-PCR analysis was performed using a SYBR PrimeScript RT-PCR Kit (Takara Bio, Shiga, Japan) and LightCycler (Roche Diagnostics KK, Tokyo, Japan). Rat $\mathrm{ET}_{\mathrm{A}}$ receptor, $\mathrm{ET}_{\mathrm{B}}$ receptor and $\mathrm{GAPDH}$ primer sequences are as follows: forward primer, 5'-CAGGAGCAG AACCACAACACA-3' $\left(\mathrm{ET}_{\mathrm{A}}\right.$ receptor), 5'-GATACGACAACTTCCGCTCCA-3' (ET ${ }_{\mathrm{B}}$ receptor), 5'-CGGTGT GAACGGATTTGG-3' (GAPDH); reverse primer, $5^{\prime}$-TGCTGCGT GACCGTT TCA-3' (ET ${ }_{\mathrm{A}}$ receptor), 5'- GTCCACGATGAGGACAATGAGA-3' (ET ${ }_{\mathrm{B}}$ receptor), 5'-TGAAGGGGTCGTTGATGG-3' (GAPDH). Comparison with GAPDH values was carried out for normalization. Relative expression levels in each sample were determined by comparison with the standard using the LightCycler3 Front software for analysis.

\section{Drugs}

Big ET-1 was obtained from Peptide Institute (Osaka, Japan). It was dissolved in a saline solution containing $0.1 \%$ heat-inactivated bovine serum albumin. A-192621 and ABT-627 were provided by Abbott Laboratories (Abbott Park, IL, USA), dissolved in ethanol and diluted to a final concentration of $0.005 \%$ ethanol in the perfusate. SM-19712 was provided by Sumitomo Pharmaceuticals (Osaka, Japan). This chemical was dissolved in Krebs-Henseleit buffer. All other reagents were obtained from Nacalai Tesque (Kyoto, Japan) and Wako Pure Chemical Industries (Osaka, Japan).

\section{Statistical analysis}

All values were expressed as mean \pm s.e.m. Relevant data were processed by InStat (Graph-PAD Software for Science, San Diego, CA, USA). For statistical analysis, we used the unpaired Student's $t$-test for two-group comparison and either one- or two-way analysis of variance combined with Bonferroni's multiple range test for multiple comparisons. Correlations were tested by Pearson's correlation test. Differences were considered significant at $P<0.05$.

\section{RESULTS}

Effects of big ET-1 on ET-1 content in coronary effluent after ischemia/reperfusion

First, we examined whether ET-1 content is enhanced with the administration of big ET-1 in the perfusion system. As shown in Figure 1, big ET-1 (0.1-1 nM) dose dependently increased ET-1 in coronary effluent from postischemic hearts measured after 5-min reperfusion.

Effects of big ET-1 on cardiac function after ischemia/reperfusion Exogenously applied big ET-1 (0.1-1 nM) produced no significant changes in basal cardiac functions, such as LVDP, $\mathrm{dP} / \mathrm{dt}_{\max }$, LVEDP and CF, before 40-min global ischemia. As shown in Figures 2a and b, the levels of LVDP and $\mathrm{dP} / \mathrm{dt}_{\max }$ were markedly reduced by ischemia, although those were gradually recovered after reperfusion. Administration of big ET-1 ( 0.3 and $1 \mathrm{~nm}$ ) significantly improved the reduction of these parameters, although effects of the lower dose were somewhat more potent compared with the higher dose. In addition, the elevation of LVEDP observed after reperfusion was significantly attenuated by these concentrations of big ET-1 (Figure 2c). Moreover, $\mathrm{CF}$ after reperfusion was significantly increased by the treatment with 0.3 nм big ET-1 (Figure 2d). 
Effects of big ET-1 on NE overflow after ischemia/reperfusion

$\mathrm{NE}$ overflow in the 5-min coronary effluent from the heart exposed to 40-min global ischemia and reperfusion $\left(37.20 \pm 2.62 \mathrm{ng} 5 \mathrm{~min}^{-1}\right)$ was much higher than the preischemic basal level $\left(1.27 \pm 0.31 \mathrm{ng} 5 \mathrm{~min}^{-1}\right)$. None of the doses of big ET-1 had any influence on the preischemic NE level (data not shown). Ischemia/reperfusion-induced enhancement of NE overflow was significantly suppressed by treatment with

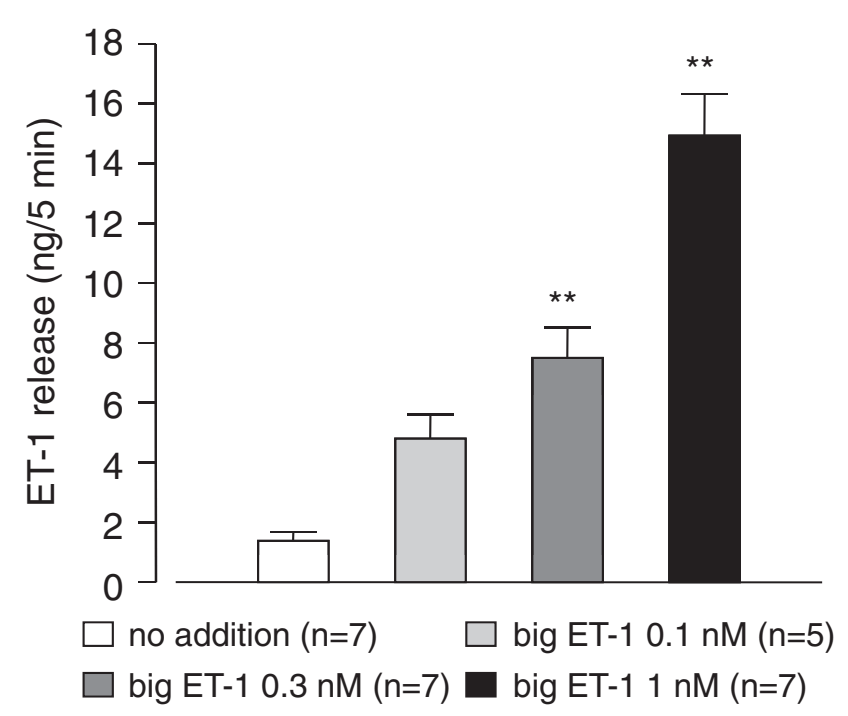

Figure 1 Influence of big ET-1 on ET-1 release after ischemia/reperfusion. Big ET-1 dose dependently increased ET-1 in the coronary effluent after ischemia/reperfusion. Each column and bar represents the mean \pm s.e.m. ${ }^{* *} P<0.01$, compared with no addition.
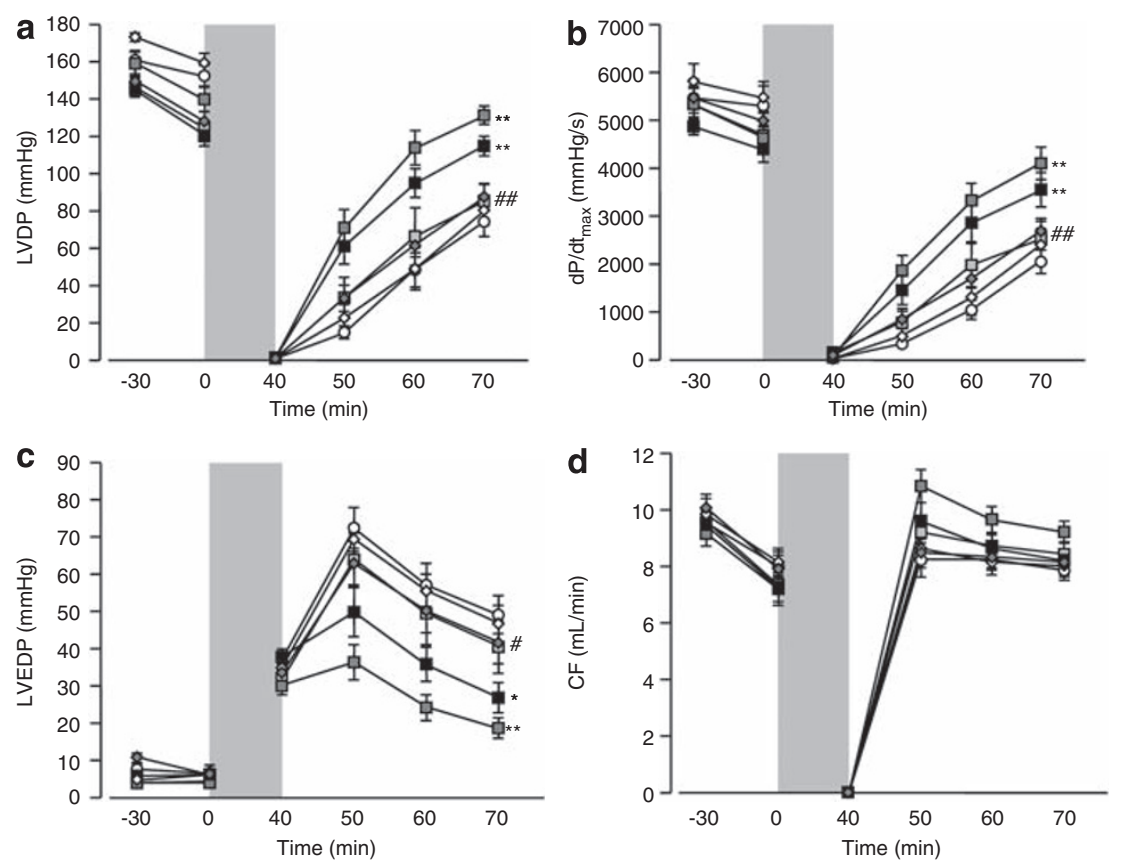

$$
\begin{aligned}
& \multimap \text { no addition }(\mathrm{n}=7) \quad \longrightarrow \text { big ET-1 } 0.1 \mathrm{nM}(\mathrm{n}=5) \multimap \mathrm{SM}-19712(\mathrm{n}=5) \\
& \neg \text { big ET-1 } 0.3 \mathrm{nM}(\mathrm{n}=7)-\text { big ET-1 } 1 \mathrm{nM}(\mathrm{n}=7) \multimap \text { big ET-1 } 0.3 \mathrm{nM}+\mathrm{SM}-19712(\mathrm{n}=7)
\end{aligned}
$$

Figure 2 Influence of big ET-1 on cardiac functions, such as LVDP (a), dP/dt $t_{\max }$ (b), LVEDP (c), CF (d), after ischemia/reperfusion in the absence or presence of ECE inhibitor. Big ET-1 at 0.3 nм most effectively improved cardiac dysfunction observed after reperfusion. SM-19712 blunted effects of $0.3 \mathrm{~nm}$ big ET-1. Each column and bar represents the mean \pm s.e.m. ${ }^{*} P<0.05$ and ${ }^{* *} P<0.01$, compared with no addition. ${ }^{\#} P<0.05$ and ${ }^{\# \#} P<0.01$, compared with 0.3 nm big ET-1.

0.3 nм big ET-1, but not with 0.1 or 1 nм big ET-1, although the latter dose tended to reduce postischemic NE overflow (Figure 3). This dose-response pattern to big ET-1 $(0.3>1>0.1 \mathrm{nM})$ was similar the case of cardiac function, suggesting that suppressive effects of -1 on the NE overflow from the postischemic heart may be closely related to the beneficial effects against the ischemia/ eperfusion-induced cardiac dysfunction. To confirm this view, the

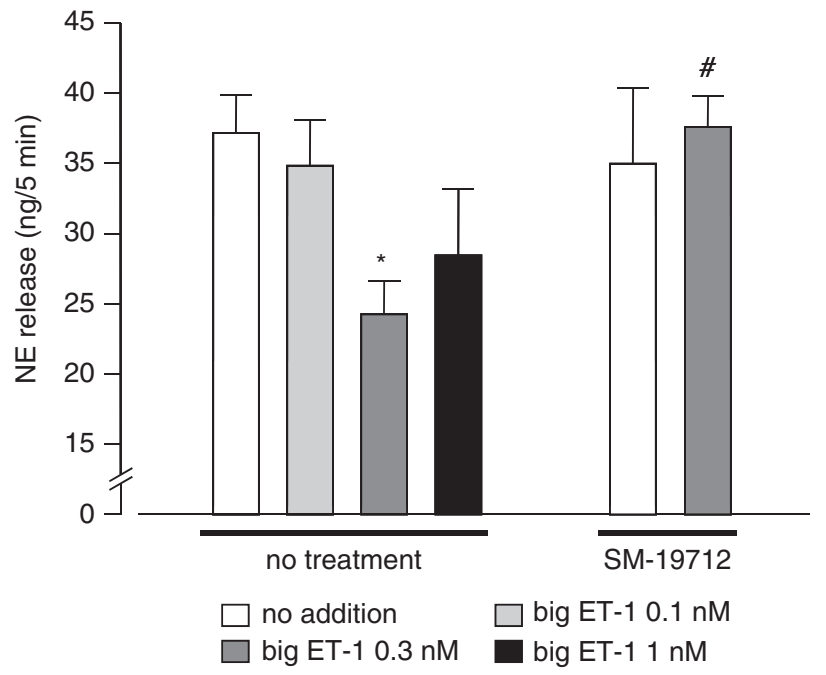

Figure 3 Influence of big ET-1 on NE overflow after ischemia/reperfusion in the absence or presence of ECE inhibitor. Big ET-1 at $0.3 \mathrm{~nm}$ most effectively suppressed NE overflow after reperfusion. SM-19712 blunted the effect of $0.3 \mathrm{~nm}$ big ET-1. Each column and bar represents the mean \pm s.e.m. ${ }^{*} P<0.05$, compared with no addition. ${ }^{\#} P<0.05$, compared with 0.3 nм big ET-1. 

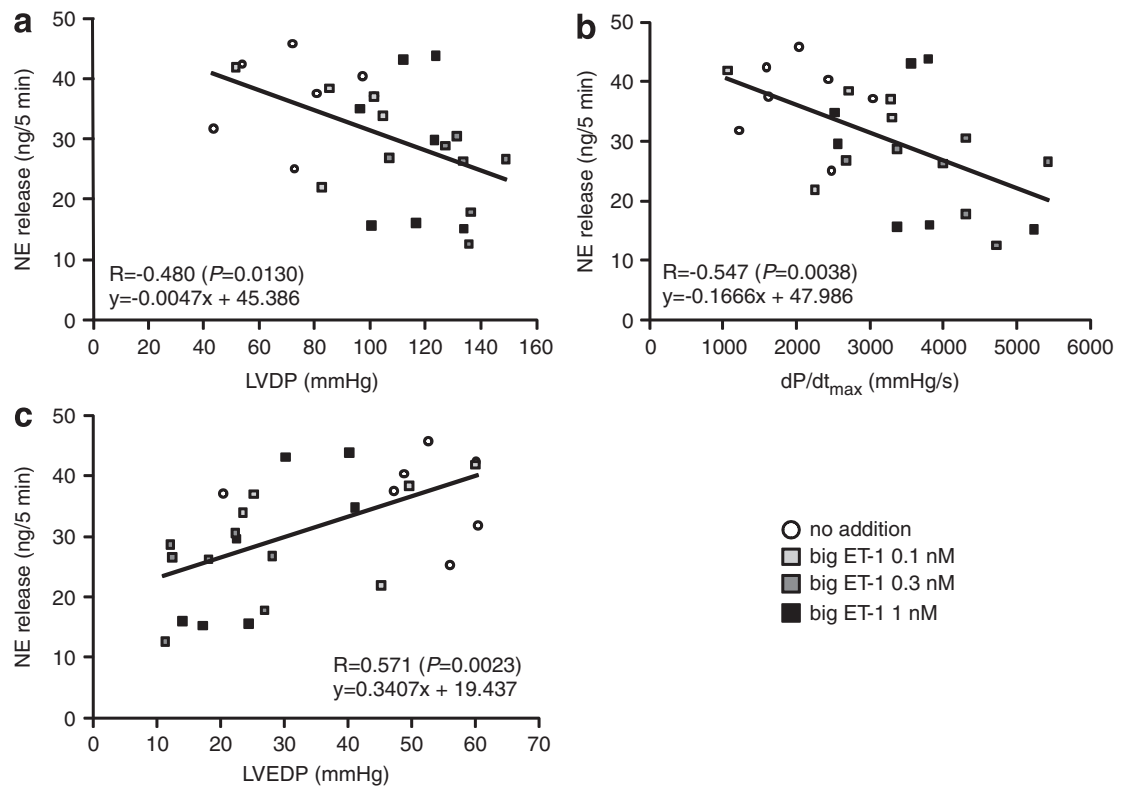

$\square$ big ET-10.1 nM

big ET-1 $1 \mathrm{nM}$

Figure 4 Relationship between NE release and $\operatorname{LVDP}(\mathbf{a}), \mathrm{dP} / \mathrm{dt}_{\max }$ (b) or LVEDP (c) at $30 \mathrm{~min}$ after reperfusion.

relationships between cardiac function parameters and NE release were analyzed. As shown in Figure 4, NE release correlated well with the change in each cardiac function parameter ( $v s$. LVDP, $r=0.480$, $P=0.0130 ; v s$. $\mathrm{dP} / \mathrm{dt}_{\max }, r=0.547, P=0.0038 ; v s$. LVEDP, $r=0.571$, $P=0.0023$.

Effects of big ET-1 on cardiac function after ischemia/reperfusion in the presence of ECE inhibitor

Treatment with SM-19712 produced no significant changes in basal levels of cardiac function parameters, in both cases with and without big ET-1. As shown in Figure 2, 0.3 nм big ET-1-induced improvement against cardiac dysfunction after ischemia/reperfusion was markedly attenuated by the combination with SM-19712.

Effects of big ET-1 on NE overflow after ischemia/reperfusion in the presence of ECE inhibitor

SM-19712 itself had no significant effects on the ischemia/reperfusioninduced augmentation of NE overflow. When big ET-1 (0.3 nM) was administered with its inhibitor, the big ET-1-induced decreasing effect on the NE overflow from the postischemic heart was significantly attenuated (Figure 3).

Effects of big ET-1 on cardiac function after ischemia/reperfusion in the presence of ET receptor antagonists

As shown in Figure 5, A-192621 significantly inhibited big ET-1induced improvement against cardiac dysfunction after ischemia/ reperfusion. On the other hand, although ABT-627 itself efficiently improved cardiac function parameters diminished by the ischemia/ reperfusion, this antagonist did not augment the beneficial effects of exogenous big ET-1.

Effects of big ET-1 on NE overflow after ischemia/reperfusion in the presence of ET receptor antagonists

A-192621 had no significant influences on the ischemia/reperfusioninduced augmentation of NE overflow, but efficiently attenuated the big ET-1-induced decreasing effect on the NE overflow from the postischemic heart. On the other hand, the combination of exogenous big ET-1 and ABT-627 did not produce a synergetic effect on the NE overflow (Figure 6).

Effects of big ET-1 on $\mathrm{ET}_{\mathrm{A}}$ and $\mathrm{ET}_{\mathrm{B}}$ receptor mRNA expression in the left ventricle

As shown in Figures $7 \mathrm{a}$ and $\mathrm{b}, \mathrm{ET}_{\mathrm{A}}$ and $\mathrm{ET}_{\mathrm{B}}$ receptor mRNA expression at preischemia, during ischemia and after reperfusion did not change significantly between with and without exogenous big ET-1.

\section{DISCUSSION}

We and others have demonstrated that cardiac ET-1 production is increased by ischemia, followed by reperfusion ${ }^{6,23}$ and that increased ET-1 is involved in the postischemic cardiac dysfunction by enhancing $\mathrm{NE}$ overflow via the stimulation of $\mathrm{ET}_{\mathrm{A}}$ receptor existing in the sympathetic nerve endings. ${ }^{7-10,14}$ In addition, we obtained evidence that exogenously applied ET-1 to the ischemic heart further enhanced the NE overflow and exacerbates the postischemic cardiac dusfunction. ${ }^{10}$ In the present study, we expected that exogenously applied big ET-1 would cause deterioration of cardiac function following the global ischemia and reperfusion, because exogenously applied big ET1 exerts qualitatively similar effects to ET-1, in the cardiovascular system in vivo and in vitro. ${ }^{16-19}$ Unexpectedly, however, one of the doses of exogenous big ET-1 (0.3 nM) suppressed ischemia/reperfusion-induced NE overflow and improved the cardiac dysfunction observed after reperfusion, in spite of the fact that ET-1 content in coronary effluent from the heart exposed to ischemia and reperfusion was increased by exogenous big ET-1 application. Sharif et al. have reported similar finding with our present results. ${ }^{24}$ In this paper, they demonstrate that exogenously applied ET-1 has opposite effects to endogenously released ET-1 on ischemic ventricular arrhythmias. We consider these findings are important information for a much better understanding about the cardiovascular effects of these molecules.

Big ET-1 exerts several physiological actions similar to ET-1, but it is necessary to be converted to ET- 1 via the enzymatic degradation by ECE. ${ }^{16-18,25}$ In the present study, the increase in ET-1 content 

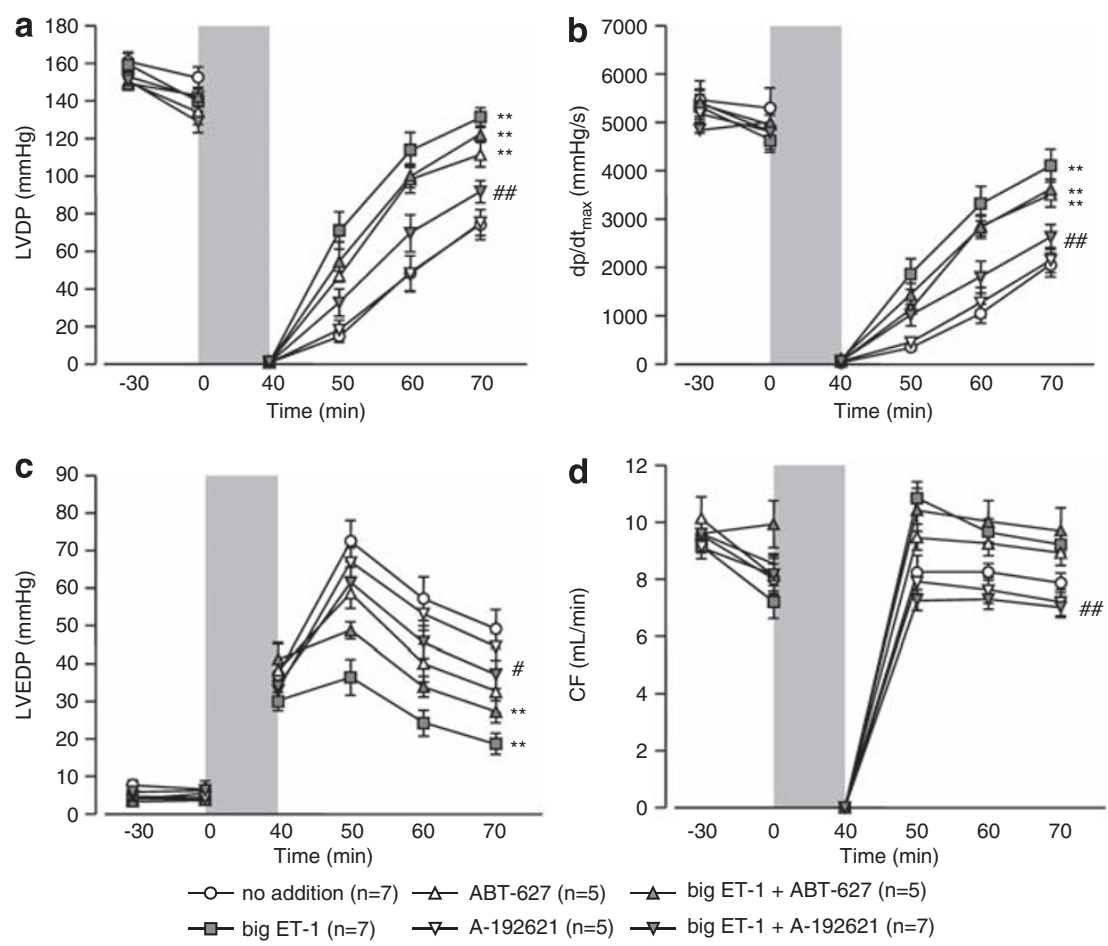

Figure 5 Influence of big ET-1 on cardiac functions, such as LVDP (a), dP/dt $t_{\max }$ (b), LVEDP (c), CF (d), after ischemia/reperfusion in the presence of ET receptor antagonists. A-19712 blunted cardioprotective effects of $0.3 \mathrm{~nm}$ big ET-1, but ABT-627 had no additional influences on those. Each column and bar represents the mean \pm s.e.m. ${ }^{* *} P<0.01$ compared with no addition. ${ }^{\#} P<0.05$ and ${ }^{\# \#} P<0.01$, compared with big ET-1.

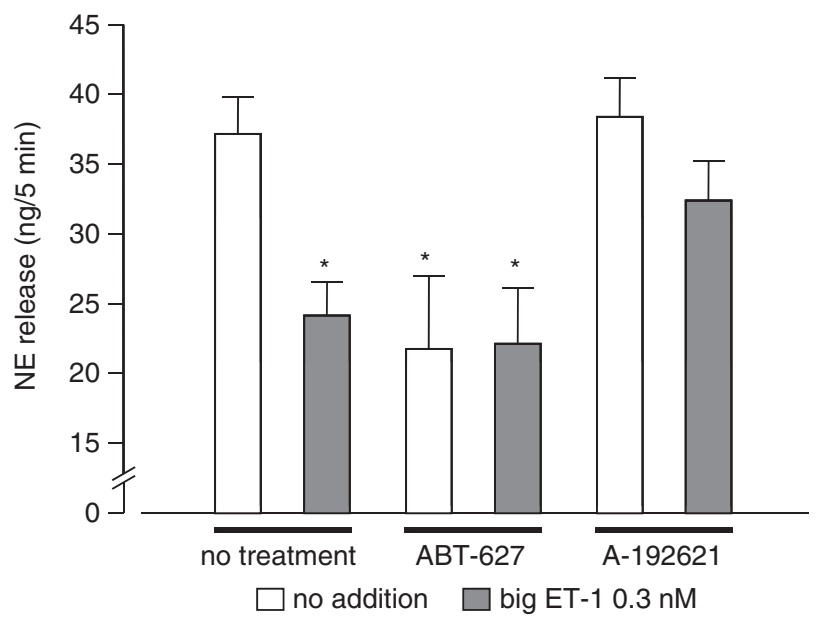

Figure 6 Influence of big ET-1 on NE overflow after ischemia/reperfusion in the presence of ET receptor antagonists. A-19712 blunted inhibitory effect of $0.3 \mathrm{~nm}$ big ET- 1 on NE overflow after reperfusion, but ABT-627 had no additional influences on it. Each column and bar represents the mean \pm s.e.m. ${ }^{*} P<0.05$, compared with no addition.

observed with the exogenous big ET-1 application was abolished by the treatment with SM-19712, a selective ECE inhibitor (data not shown). Furthermore, SM-19712 reversed the exogenous big ET-1induced amelioration of cardiac dysfunction and suppression of NE overflow, indicating that big ET-1-induced alterations on cardiac dysfunction after ischemia/reperfusion injury are due to the mature ET-1 converted through the ECE action.

Two subtypes of ET-1 receptor, named $\mathrm{ET}_{\mathrm{A}}$ and $\mathrm{ET}_{\mathrm{B}}$, are known to mediate opposite physiological actions in several organs, including $\mathrm{NE}$ release from sympathetic nerve endings of the postischemic heart; $\mathrm{ET}_{\mathrm{A}}$ receptors evoke NE release, whereas $\mathrm{ET}_{\mathrm{B}}$ receptors prevent it. ${ }^{10,14}$ Most recently, Oikonomidis et al. found a prominent role of $\mathrm{ET}_{\mathrm{B}}$ receptor on sympathetic hyperactivity during the early phase of myocardial infarction. ${ }^{13}$ In this study, they have demonstrated that NE level during the early phase of myocardial infarction is much higher in $\mathrm{ET}_{\mathrm{B}}$ deficient rats than wild-type rats and this contributes to incidence of ventricular arrhythmogenesis. In the present study, exogenously applied big ET-1 suppressed NE overflow in the coronary effluent after ischemia/reperfusion. Therefore, the involvement of $\mathrm{ET}_{\mathrm{B}}$ receptor rather than $\mathrm{ET}_{\mathrm{A}}$ receptor was speculated. In this regard, the treatment with big ET-1 in the presence of A-192621, a selective $\mathrm{ET}_{\mathrm{B}}$ receptor antagonist, failed to exert beneficial effects against ischemia/reperfusion-induced NE overflow and subsequent cardiac dysfunction. Thus, it seems likely that $\mathrm{ET}_{\mathrm{B}}$ receptor-mediated events are mainly involved in the big ET-1-induced actions.

In the present study, cardioprotective effects of exogenous big ET-1 were somewhat more potent in the middle dose compared with those in the high dose. In this regard, we obtained the result that ABT-627 dose not potentiate the $0.3 \mathrm{~nm}$ big ET-1-induced beneficial effects on cardiac ischemia/reperfusion injury. This result suggests the possibility that $\mathrm{ET}_{\mathrm{B}}$ receptor is already saturated by the treatment of this dose of big ET-1. It is easy to assume that even though ET-1 produced by exogenous big ET-1 preferentially binds to $\mathrm{ET}_{\mathrm{B}}$ receptors, excessively generated ET-1 acts on not only $\mathrm{ET}_{\mathrm{B}}$ receptors but also other receptors, possibly $\mathrm{ET}_{\mathrm{A}}$ receptors. Previously, we have demonstrated that the activation of $\mathrm{ET}_{\mathrm{A}}$ receptors has detrimental effects on cardiac ischemia/reperfusion injury. ${ }^{6,10}$ Therefore, we consider this is the one reason why exogenously applied big ET-1-induced effects are bell shaped.

Although there are many signaling pathways in downstream of $\mathrm{ET}_{\mathrm{B}}$ receptor, nitric oxide is thought to act as the key mediator, because 

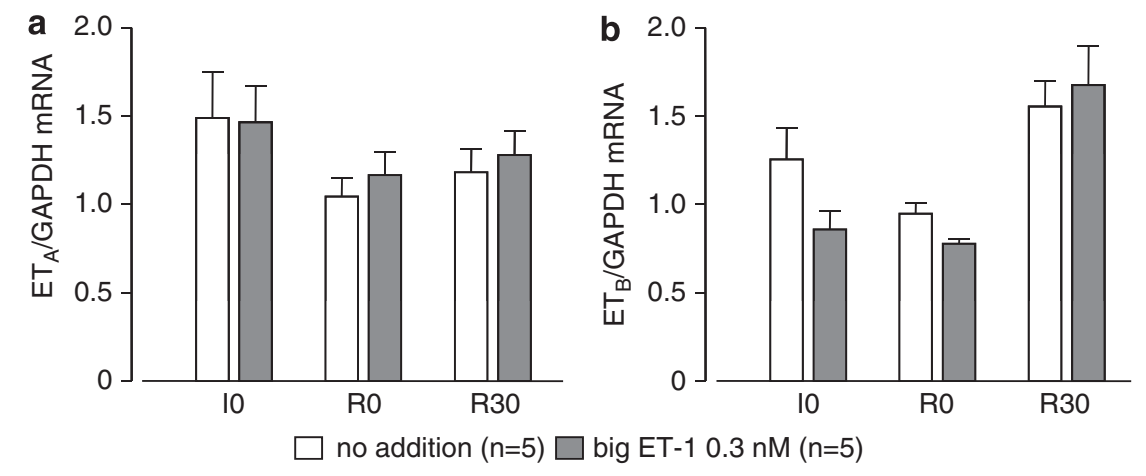

Figure 7 Influence of big $\mathrm{ET}-1$ on $\mathrm{ET}_{\mathrm{A}}(\mathbf{a})$ and $\mathrm{ET}_{\mathrm{B}}$ (b) receptors mRNA expression in the left ventricle. These expressions did not change significantly between with and without $0.3 \mathrm{~nm}$ big ET-1. 10, preischemia; R0, 0 min after reperfusion; R30, 30 min after reperfusion. Each column and bar represents the mean \pm s.e.m.

nitric oxide synthase inhibition can inhibit $\mathrm{ET}_{\mathrm{B}}$ receptor-mediated responses. ${ }^{26}$ In the present study, we cannot identify the downstream of $\mathrm{ET}_{\mathrm{B}}$ receptor stimulation, but $\mathrm{CF}$ after ischemia/reperfusion markedly increased after treatment with big ET-1, possibly implicating vasorelaxing factor(s). In addition, we have recently reported that nitric oxide has an inhibitory effect on NE overflow after cardiac ischemia/reperfusion. ${ }^{27}$ Therefore, we presume whether nitric oxide acts as the downstream mediator of $\mathrm{ET}_{\mathrm{B}}$ receptor activation by ET-1 generated from exogenously applied big ET-1 via ECE.

It has been mentioned that ET-1 plays a critical role in heart injury mostly through the activation of $\mathrm{ET}_{\mathrm{A}}$ receptors. ${ }^{7,9,10,14}$ However, our present data showed that ET-1 generated from exogenously applied big ET-1 preferentially acts on $\mathrm{ET}_{\mathrm{B}}$ receptors rather than $\mathrm{ET}_{\mathrm{A}}$ receptors in the postischemic heart. In the present study, we have chosen the doses of exogenous big ET- 1 in the ranges from 0.1 to $1 \mathrm{~nm}$. If we calculate the converting ratio of exogenously applied big ET-1 to ET-1 based on data from Figure 1, it is roughly around $25 \%$ or so. Therefore, the final concentrations of ET- 1 in perfusate after treatment with these doses of big ET- 1 are similar to the conditions of our previous experiment using $0.03-0.1 \mathrm{~nm}$ exogenous ET- $1 .{ }^{10}$ This indicates that the reason for above discrepancy is not due to the difference of ET-1 level. On the other hand, a previous study has demonstrated that the status of high big ET-1 level leads to a change of ET-1 receptor expression. ${ }^{28}$ Therefore, as the reason for above discrepancy, there is one possibility that exogenous big ET-1 produces an altered ET-1 receptor expression. In the present study, however, the treatment with big ET-1 had no significant influence on the level of both $\mathrm{ET}_{\mathrm{A}}$ and $\mathrm{ET}_{\mathrm{B}}$ receptor mRNA expression in the left ventricle.

Recent work shows that ECE-1, a dominant subtype of ECE, colocalizes with $\mathrm{ET}_{\mathrm{B}}$ receptor in the kidney. ${ }^{29}$ ECE-1 mRNA has been shown to be expressed in various organs, including the lung, adrenal gland, heart, ovary and testis, and most abundantly in vascular endothelial cells. ${ }^{15,30}$ Accordingly, there is a possibility that ECE-1 and $\mathrm{ET}_{\mathrm{B}}$ receptor colocalize within somewhere of cardiac tissues. If so, endogenously generated ET-1 should also act preferentially on $\mathrm{ET}_{\mathrm{B}}$ receptors. ECE-1 is classified into four isoforms by the difference of subcellular distribution in rat. ${ }^{31}$ Emoto et al. have described that the isoform cleaving big ET-1 is different between endogenously synthesized and exogenously supplied one; the former is mainly catalyzed by isoform expressing intracellular, whereas the latter is cleaved by it expressing on the cell surface. ${ }^{32}$ Based on this report, endogenously increased ET-1 in the postischemic heart should be mostly generated inside the cell, whereas exogenously applied big ET-1 may be cleaved at cell surfaces. If this isoform expressing on the cell surface is close to
$\mathrm{ET}_{\mathrm{B}}$ receptors, we can explain why ET-1 produced by exogenous big ET-1 preferentially acts on $\mathrm{ET}_{\mathrm{B}}$ receptors but not on $\mathrm{ET}_{\mathrm{A}}$ receptors. However, further investigations are required to clarify this hypothesis.

\section{CONCLUSION}

Our findings suggest that appropriate amount of exogenous big ET-1 suppresses NE overflow and improves cardiac dysfunction after ischemia/reperfusion, and these effects mediate through a conversion to ET-1 by ECE and following stimulation of $\mathrm{ET}_{\mathrm{B}}$ receptor.

\section{ACKNOWLEDGEMENTS}

This work was supported in part by a 'High-Tech Research Center' Project for Private Universities: matching fund subsidy from the Ministry of Education, Culture, Sports, Science and Technology (2007-2009).

1 Yanagisawa M, Kurihara H, Kimura S, Tomobe Y, Kobayashi M, Mitsui Y, Yazaki Y, Goto K, Masaki T. A novel potent vasoconstrictor peptide produced by vascular endothelial cells. Nature 1998; 332: 411-415.

2 Lüscher TF, Barton M. Endothelins and endothelin receptor antagonists: therapeutic considerations for a novel class of cardiovascular drugs. Circulation 2000; 102: 2434-2440.

3 Schiffrin EL. Role of endothelin-1 in hypertension and vascular disease. Am J Hypertens 2001; 14: 83S-89S.

4 Fujii H, Takiuchi S, Kamide K, Horio T, Niizuma S, Tanaka N, Hashimoto S, Nakatani S, Fukagawa M, Kawano Y. Clinical implications of assessing coronary flow velocity reserve and plasm endothelin-1 in hypertensive patients. Hypertens Res 2005; 28: 911-916.

5 Watanabe T, Suzuki N, Shimamoto N, Fujino M, Imada A. Contribution of endogenous endothelin to the extension of myocardial infarct size in rats. Circ Res 1991; 69: 370-377.

6 Tawa M, Fukumoto T, Ohkita M, Matsumura Y. Role of endogenous endothelin-1 in postischemic cardiac dysfunction and norepinephrine overflow in rat hearts. Eur J Pharmacol 2008; 591: 182-188.

7 Han H, Neubauer S, Braeker B, Ertl G. Endothelin-1 contributes to ischemia/reperfusion injury in isolated rat heart-attenuation of ischemic injury by the endothelin-1 antagonists BQ123 and BQ610. J Mol Cell Cardiol 1995; 27: 761-766.

$8 \mathrm{Li} \mathrm{XS}$, Wang QD, Pernow J. Beneficial effects of the endothelin receptor antagonist bosentan on myocardial and endothelial injury following ischaemia/reperfusion in the rat. Eur J Pharmacol 1995; 283: 161-168.

9 Illing B, Horn M, Han H, Hahn S, Bureik P, Ertl G, Neubauer S. Protective effect of the specific endothelin-1 antagonist BQ610 on mechanical function and energy metabolism during ischemia/reperfusion injury in isolated perfused rat hearts. J Cardiovasc Pharmacol 1996; 27: 487-494.

10 Yamamoto S, Matsumoto N, Kanazawa M, Fujita M, Takaoka M, Gariepy CE, Yanagisawa M, Matsumura Y. Different contributions of endothelin-A and endothelin-B receptors in postischemic cardiac dysfunction and norepinephrine overflow in rat hearts. Circulation 2005; 111: 302-309.

11 Schömig A, Haass M, Richardt G. Catecholamine release and arrhythmias in acute myocardial ischemia. Eur Heart J 1991; 12(suppl F): 38-47.

12 Imamura M, Lander HM, Levi R. Activation of histamine $\mathrm{H}_{3}$ receptors inhibits carriermediated norepinephrine release during protracted myocardial ischemia: comparison with adenosine A1-receptors and $\alpha 2$-adrenoceptors. Circ Res 1996; 78: 475-481. 
13 Oikonomidis DL, Tsalikakis DG, Baltogiannis GG, Tzallas AT, Xourgia X, Agelaki MG, Megalou AJ, Fotopoulos A, Papalois A, Kyriakides ZS, Kolettis TM. Endothelin-B receptors and ventricular arrhythmogenesis in the rat model of acute myocardial infarction. Basic Res Cardiol 2010; 105: 235-245.

14 Isaka M, Kudo A, Imamura M, Kawakami H, Yasuda K. Endothelin receptors, localized in sympathetic nerve terminals of the heart, modulate norepinephrine release and reperfusion arrhythmias. Basic Res Cardiol 2007; 102: 154-162.

15 Xu D, Emoto N, Giaid A, Slaughter C, Kaw S, deWit D, Yanagisawa M. ECE-1: a membrane-bound metalloprotease that catalyzes the proteolytic activation of big endothelin-1. Cell 1994; 78: 473-485.

16 Matsumura Y, Hisaki K, Takaoka M, Morimoto S. Phosphoramidon, a metalloproteinase inhibitor, suppresses the hypertensive effect of big endothelin-1. Eur J Pharmacol 1990; 185: 103-106.

17 Trapani AJ, De Lombaert S, Kuzmich S, Jeng AY. Inhibition of big ET-1-induced pressor response by an orally active dual inhibitor of endothelin-converting enzyme and neutral endopeptidase 24.11. J Cardiovasc Pharmacol 1995; 26: S69-S71.

18 Fecteau MH, Honoré JC, Plante M, Labonté J, Rae GA, D'Orléans-juste P. Endothelin-1 (1-31) is an intermediate in the production of endothelin-1 after big endothelin-1 administration in vivo. Hypertension 2005; 46: 87-92.

19 Grover GJ, Sleph PG, Fox M, Trippodo NC. Role of endothelin-1 and big endothelin-1 in modulating coronary vascular tone, contractile function and severity of ischemia in rat hearts. J Pharmacol Exp Ther 1992; 263: 1074-1082.

20 Umekawa K, Hasegawa H, Tsutsumi Y, Sato K, Matsumura Y, Ohashi N. Pharmacological characterization of a novel sulfonylureid-pyrazole derivative, SM-19712, a potent nonpeptidic inhibitor of endothelin converting enzyme. Jpn J Pharmacol 2000; 84: 7-15.

21 von Geldern TW, Tasker AS, Sorensen BK, Winn M, Szczepankiewicz BG, Dixon DB, Chiou WJ, Wang L, Wessale JL, Adler A, Marsh KC, Nguyen B, Opgenorth TJ. Pyrrolidine-3-carboxylic acids as endothelin antagonists, 4: side chain conformational restriction leads to $\mathrm{ET}_{\mathrm{B}}$ selectivity. J Med Chem 1999; 42: 3668-3678.

22 Opgenorth TJ, Adler AL, Calzadilla SV, Chiou WJ, Dayton BD, Dixon DB, Gehrke LJ, Hernandez L, Magnuson SR, Marsh KC, Novosad EI, Von Geldern TW, Wessale JL, Winn M, Wu-Wong JR. Pharmacological characterization of A-127722: an orally active and

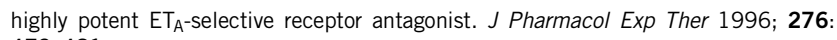
473-481.

23 Brunner F, Du Toit EF, Opie LH. Endothelin release during ischemia and reperfusion of isolated perfused rat hearts. J Mol Cell Cardiol 1992; 24: 1291-1305.

24 Sharif I, Kane KA, Wainwright CL. Endothelin and ischaemic arrhythmias-antiarrhythmic or arrhythmogenic? Cardiovasc Res 1998; 39: 625-632.

25 Pollock DM, Divish BJ, Novosad EI, Burres NS, Opgenorth TJ. In vivo characterization of a phosphoramidon-sensitive endothelin converting enzyme in the rat. Eur J Pharmacol 1993; 231: 459-464.

26 Matsuo G, Matsumura Y, Tadano K, Hashimoto T, Morimoto S. Effects of sarafotoxin $\mathrm{S} 6 \mathrm{c}$ on renal haemodynamics and urine formation in anaesthetized dogs. Clin Exp Pharmacol Physiol 1997; 24: 487-491.

27 Tawa M, Fukumoto T, Yamashita N, Ohkita M, Ayajiki K, Okamura T, Matsumura Y. Postconditioning improves post-ischemic cardiac dysfunction independently of norepinephrine overflow after reperfusion in rat hearts: comparison with preconditioning. J Cardiovasc Pharmacol 2010; 55: 6-13.

28 Serneri GG, Cecioni I, Vanni S, Paniccia R, Bandinelli B, Vetere A, Janming $X$ Bertolozzi I, Boddi M, Lisi GF, Sani G, Modesti PA. Selective upregulation of cardiac endothelin system in patients with ischemic but not idiopathic dilated cardiomyopathy: endothelin-1 system in the human failing heart. Circ Res 2000; 86: 377-385.

29 Khamaisi M, Raz I, Shilo V, Rosenberger C, Dahan R, Abassi Z, Meidan R, Lecht S, Heyman SN. Diabetes and radiocontrast media increase endothelin converting enzyme1 in the kidney. Kidney Int 2008; 74: 91-100.

30 Shimada K, Takahashi M, Tanzawa K. Cloning and functional expression of endothelin-converting enzyme from rat endothelial cells. J Biol Chem 1994; 269: $18275-18278$.

31 Valdenaire O, Lepailleur-Enouf D, Egidy G, Thouard A, Barret A, Vranckx R, Tougard C, Michel JB. A fourth isoform of endothelin-converting enzyme (ECE-1) is generated from an additional promoter. Eur J Biochem 1999; 264: 341-349.

32 Emoto N, Nurhantari Y, Alimsardjono H, Xie J, Yamada T, Yanagisawa M, Matsuo M. Constitutive lysosomal targeting and degradation of bovine endothelin-converting enzyme-1a mediated by novel signals in its alternatively spliced cytoplasmic tail. J Biol Chem 1999; 274: 1509-1518. 